\title{
EARLY AND LATE ASSESSMENT OF ESOPHAGOCARDIOPLASTY IN THE SURGICAL TREATMENT OF ADVANCED RECURRENT MEGAESOPHAGUS
}

\author{
José Luis Braga de AQUINO'1, Marcelo Manzano SAID¹, Douglas Alexandre Rizzanti PEREIRA', \\ Vânia Aparecida LEANDRO-MERHI², Paula Casals do NASCIMENTO ${ }^{3}$ and Virgínia Vieitez REIS ${ }^{3}$
}

\begin{abstract}
Background - Since Chagas disease has esophageal manifestations with different degrees of involvement, the best surgical option is controversial, especially for patients with advanced chagasic megaesophagus and recurrent symptoms after previous treatment. Objective - To assess the early and late outcomes of esophagocardioplasty in a series of patients with advanced recurrent chagasic megaesophagus. Methods - This descriptive study included 19 older patients with recurrent megaesophagus grade III/IV and positive immunofluorescence for Chagas disease. They had undergone cardiomyotomy with anterior fundoplication a mean of 16.5 years ago. Serra-Doria esophagocardioplasty was selected to treat the recurrence. The patients were followed to assess postoperative and late complications and the incidence of symptom recurrence. Results - In early assessment, five (26.3\%) patients presented clinical complications. One (5.2\%) patient had a gastrointestinal fistula secondary to esophagogastric anastomotic leak, which responded well to conservative treatment. In the one-year follow-up, $18(94.7 \%)$ patients could swallow normally and had no vomiting. Three years after surgery, $10(62.5 \%)$ of 16 patients could swallow normally, and $3(19.3 \%)$ patients complained of vomiting. Five years after surgery, only $5(38.4 \%)$ of 13 patients could swallow normally and $7(53.8 \%)$ had vomiting. Conclusion - Serra-Doria esophagocardioplasty for the treatment of advanced recurrent megaesophagus had mild postoperative complications and good success rate in the short-term follow-up. In the long-term follow-up, it proved to be a poor surgery choice because of the high incidence of symptom recurrence, compromising quality of life. This procedure should be indicated only for patients with advanced recurrent megaesophagus without clinical conditions to undergo esophageal resection.
\end{abstract}

HEADINGS - Esophageal acalasia, surgery. Esophagoplasty. Recurrence. Chagas disease, surgery. Aged

\section{INTRODUCTION}

Despite successful government programs to control the vector of Chagas disease, especially in the 1970s and 1980s, Chagas disease remains endemic in 21 Latin American countries, with 16 to 18 million people infected and another 100 million at risk of acquiring the disease ${ }^{(11,12)}$. It is estimated that almost eight million people are infected in Brazil, and every year the disease kills a mean of 17,000 people ${ }^{(8)}$. Eight to $40 \%$ of Chagas disease patients have esophageal manifestations with different degrees of involvement, which causes a major socioeconomic problem in our country and reduces the patients' quality of life because of dysphagia, often severe ${ }^{(19,21)}$.

Therefore, it is important to provide an effective therapy with low morbidity in an attempt to correct the impaired swallowing of these patients. Surgery represents the best form of treatment as it alleviates symptoms and improves nutritional status. This is very evident in non-advanced, treatment-naive megaesophagus, for which cardiomyotomy with fundoplication has achieved better outcomes than other techniques, since it is a simpler and more conservative surgery ${ }^{(6,7,16)}$.

However, major controversies emerge regarding the best megaesophagus surgery option for patients with symptom recurrence after previous treatment. The proposed alternatives vary depending on the etiology of recurrence. Thus, for non-advanced megaesophagus with symptom recurrence due to incomplete myotomy or fibrosis, laparotomic or laparoscopic myotomy with fundoplication is recommended ${ }^{(4,15,18,29)}$.

Esophagocardioplasty with partial Roux-en-Y gastrectomy proposed by Serra-Doria et. al. ${ }^{(30,31)}$ for the treatment of first-time or recurrent megaesophagus has become more widely discussed by other authors in the last years ${ }^{(13,25,26)}$. Nevertheless, no series has found a more specific indication for the procedure proposed by Serra-Doria, because the series studied so far included patients with very different grades of megaesophagus, ranging from grade I to more advanced $\operatorname{grades}^{(1,9,25)}$.

${ }^{1}$ Clínica Cirúrgica, Faculdade de Medicina, PUC-Campinas, SP, Brasil; ${ }^{2}$ Faculdade de Nutrição, PUC-Campinas, SP, Brasil; ${ }^{3}$ Serviço de Cirurgia, Hospital e Maternidade Celso Pierro, PUC-Campinas, SP, Brasil.

Correspondence: José Luis Braga de Aquino. Pontifícia Universidade Católica de Campinas - Departamento de Cirurgia. Boaventura do Amaral, 1190, ap. 12 CEP: 13015-192 - Centro - Campinas, SP, Brasil. E-mail: jlaquino@sigmanet.com.br 
Recently, this led Aquino et al. ${ }^{(5)}$ to propose the esophagocardioplasty technique described by Serra-Doria for non-advanced recurrent megaesophagus. These authors studied 32 patients with recurrent megaesophagus grade II after cardiomyotomy who were submitted to this type of esophagocardioplasty, and $81.4 \%$ of the sample presented good outcomes.

For advanced recurrent megaesophagus, the therapy of choice has been esophagectomy without thoracotomy, or esophageal mucosectomy with conservation of the tunica muscularis and esophageal replacement by gastric transposition to the cervical region ${ }^{(2,3,20,22,24)}$.

Consequently, the following idea emerges: proposing Serra-Doria esophagocardioplasty as the standard therapy exclusively for advanced recurrent megaesophagus in patients who do not have the clinical conditions to undergo more complex surgical techniques, such as esophagectomy or esophageal mucosectomy.

Therefore, the objective of this study was to assess the early and late outcomes of esophagocardioplasty with partial Roux-en-Y gastrectomy, and the systemic and local postoperative complications in a series of patients with advanced megaesophagus and symptom recurrence after myotomy.

\section{METHODS}

\section{Casuistic, study type and location, and inclusion and exclusion criteria}

This is a descriptive study conducted at the Surgery Service of the Hospital and Maternity Hospital Celso Pierro, of Puc-Campinas-SP-Brazil, from January 1996 to December 2014 after approval of the local Research Ethics Committee. The sample consisted of 19 patients with advanced megaesophagus and symptom recurrence after myotomy. Their clinical conditions enabled them to undergo Serra-Doria esophagocardioplasty. The inclusion criteria were having advanced recurrent chagasic megaesophagus, having undergone the same surgery (cardiomyotomy), and having a postoperative follow-up of at least 1 year. The exclusion criteria were having non-advanced megaesophagus, being treatment naïve, having other non-chagasic megaesophagus etiologies, having a previous surgery other than cardiomyotomy, and being lost to follow-up before the one-year follow-up.

\section{Preoperative assessment}

The following parameters were assessed preoperatively:

a. Clinical assessment: Seven $(36.8 \%)$ patients presented moderate dysphagia (for soft foods), and $12(63.2 \%)$ patients presented intense dysphagia (for liquid foods) for 3 to 14 years. Thirteen $(68.3 \%)$ patients also presented vomiting and reported having lost 8 to $21 \mathrm{~kg}$ in 18 to 37 months. All 13 patients had smoked 20 to 30 cigarettes a day for more than 15 years, and 7 patients had consumed 2 to 3 units of distilled alcoholic beverages per day for more than 20 years. They had undergone cardiomyotomy 7 to 29 years ago. All patients had positive immunofluorescence test for Chagas disease. b. Radiological assessment: contrast radiography of the esophagus evidenced megaesophagus grade III in six $(36.3 \%)$ patients and grade IV in $13(73.7 \%)$ patients according to the classification proposed by Rezende et. al. ${ }^{(27)}$.

c. Endoscopic assessment: upper gastrointestinal endoscopy showed esophagitis Los Angeles grade A/B in six $(36.3 \%)$ patients, grade C/D in $11(57.8 \%)$ patients, and normal in two patients.

d. Manometric assessment: esophageal manometry showed no relaxation of the lower esophageal sphincter in all nine patients submitted to the procedure, and a mean esophageal contraction amplitude of 8 to $14.5 \mathrm{mmHg}$.

Preoperative clinical assessment found cardiomyopathy and chronic obstructive pulmonary disease in all patients, so they had no clinical conditions to undergo more complex surgeries, such as esophagectomy. Eleven patients had to receive enteral nutrition for 15 to 25 days before surgery because their weight was $10 \%$ lower than the ideal weight.

\section{Surgical technique}

The surgery of choice was esophagocardioplasty with partial gastrectomy (Serra-Doria technique), which basically consists of:

a. upper midline laparotomy;

b. adhesiolysis of previous surgical adhesions and esophageal isolation;

c. laterolateral esophagogastric anastomosis in two continuous suture plans by manual technique;

d. partial gastrectomy with termino-lateral Roux-en-Y gastrojejunal anastomosis with two continuous suture plans by manual technique;

e. closure of the abdominal wall by planes and placement of a contralateral drainage tube.

\section{Postoperative assessment}

Systemic and local complications were assessed postoperatively. Systemic complications notably included cardiovascular and pleuropulmonary complications diagnosed by clinical assessment and imaging. Local complications particularly included esophagogastric and gastrojejunal anastomotic leakages and esophagogastric anastomotic stricture.

The leakage and consequent fistula of the esophagogastric and/or gastrojejunal anastomoses were diagnosed by clinical parameters, hemodynamic changes, and gastrointestinal secretion in the abdominal drainage tube 3 to 7 days after surgery. If there were no clinical evidence of anastomotic fistulas after the seventh day, and the patients presented no contrast extravasation from the anastomoses, oral diet was initiated.

Esophagogastric anastomotic stenosis was diagnosed clinically based on the presence of dysphagia thirty days after surgery, confirmed by contrast radiography and upper gastrointestinal endoscopy, both of which evidenced the decrease of the esophagogastric anastomotic diameter. 
Late postoperative assessments were conducted 1, 3, and 5 years after surgery to verify the presence of vomiting and impaired swallowing. Dysphagia, when present, was classified as mild (for solid foods), moderate (for soft foods), and severe (for liquid foods).

\section{RESULTS}

The sample consisted of $14(73.6 \%)$ males and $5(26.4 \%)$ females aged 63 to 78 years. In the 30 days after surgery, $4(21 \%)$ patients had pulmonary infection, which responded well to specific clinical treatment, and one (5.7\%) patient had tachycardia, which was reversed with specific heart treatment but delayed hospital discharge.

Regarding local complications, the esophagus of one patient was perforated during dissection, but the perforation was sutured immediately. The patient recovered well after surgery.

Eighteen $(94.7 \%)$ patients had no clinical evidence of esophagogastric or gastrojejunal anastomotic fistula in the seven days after surgery. On the seventh day they underwent contrast radiography. Since no contrast extravasation was found at the anastomotic level, oral diet was initiated, starting with liquid foods, then soft foods, and finally solid foods at the patient's request. One $(5.7 \%)$ patient presented gastrointestinal secretion in the abdominal drainage tube on the sixth day after surgery, characterizing an esophagogastric anastomotic fistula. Since the patient was hemodynamically stable and had no clinical signs of diffuse peritoneal irritation, the patient was submitted to conservative treatment consisting of daily dressings of the surgical incision and parenteral nutrition to maintain adequate nutritional status, as the patient was unable to eat. This treatment continued until the eighteenth day after surgery, when clinical evidence of the fistula had disappeared. On this day, contrast radiography did not evidence any contrast extravasation at the esophagogastric anastomotic level. The patient then initiated oral diet, starting with liquid foods, then soft foods, and finally solid foods at the patient's request.

In the late assessment, conducted up to 5 years after surgery, some patients presented recurrent dysphagia (Table 1). Only one $(5.3 \%)$ patient presented mild dysphagia 1 year after surgery. Eight (61.6\%) of the 13 study patients presented mild, moderate, or severe dysphagia five years after surgery. The same pattern was found for vomiting, since no patient complained of vomiting in the one-year follow-up, but in the five-year follow-up, seven ( $53.8 \%)$ patients did, and most were of moderate or high intensity.

TABLE 1. Late postoperative assessment of patients submitted to Serra-Doria esophagocardioplasty

\begin{tabular}{lccc}
\hline $\begin{array}{l}\text { Follow-up / } \\
\mathbf{n}^{\circ} \text { of patients }\end{array}$ & $\begin{array}{c}\text { 1 year } \\
\text { (19 patients) }\end{array}$ & $\begin{array}{c}\text { 3 years } \\
(16 \text { patients })\end{array}$ & $\begin{array}{c}5 \text { years } \\
(13 \text { patients })\end{array}$ \\
\hline Normal swallowing - n (\%) & $18(94.7)$ & $10(62.5)$ & $5(38.4)$ \\
Mild dysphagia - n (\%) & $1(5.3)$ & $4(25)$ & $2(15.3)$ \\
Moderate dysphagia - n (\%) & - & $2(12.5)$ & $4(30.4)$ \\
Severe dysphagia - n (\%) & - & - & $2(15.3)$ \\
Vomiting - n $(\%)$ & - & $3(19.3)$ & $7(53.8)$ \\
\hline
\end{tabular}

\section{DISCUSSION}

Surgical treatment of recurrent megaesophagus is still very controversial because of technical errors in the first surgery, incorrect choice of surgical technique for a given megaesophagus grade, and great variability of techniques, some of them not very efficacious ${ }^{(23,29)}$. Moreover, choosing the ideal surgical technique is difficult mainly because of the different follow-up times, poor local anatomic conditions, patients' poor nutritional status, and ignorance of the previous surgical technique ${ }^{(4,10,19)}$.

Since cardiomyotomy is the most common surgery for megaesophagus, most series report the recurrence of dysphagia after this surgery, which is usually a consequence of incomplete myotomy, fibrosis in the esophagogastric junction, and gastroesophageal reflux with esophagitis, especially in patients operated for non-advanced megaesophagus ${ }^{(4,7,15,16,18,29)}$. Symptom recurrence due to incomplete myotomy generally occurs in the first months after surgery. Dysphagia from fibrosis or esophagitis tends to appear 1 or 2 years after cardiomyotomy, as has been reported by many series ${ }^{(4,6,16,23,28,29)}$.

Hence, it is important to assess the patient's medical history thoroughly. The study patients were assessed properly: cardiomyotomy was the first surgery in all 19 study patients, and in all of them, symptoms only started to recur 5 years after the procedure. Therefore, recurrence may have stemmed from fibrosis or gastroesophageal reflux.

Some authors have recommended a second cardiomyotomy complemented by partial fundoplication in patients with non-advanced megaesophagus who have symptom recurrence after incomplete cardiomyotomy or fibrosis ${ }^{(4,7,15,16,29)}$.

Some years ago, Holt \& Large ${ }^{(17)}$ suggested the use of Roux-en-Y gastrectomy to treat megaesophagus with severe esophagitis secondary to the cardioplasty recommended by Grondhal ${ }^{(14)}$. Serra-Doria et al. ${ }^{(30,31)}$ then recommended this procedure in Brazil, associated with cardioplasty of Grondhal and partial Roux-en-Y gastrectomy to facilitate esophageal emptying and to prevent alkaline reflux to the esophagus. Since then, this procedure has been known in Brazil as the Serra-Doria surgery. This led many authors to choose the procedure for surgery-naive patients or patients with symptom recurrence, often assessing megaesophagus grade properly and indicating the procedure even for advanced megaesophagus ${ }^{(1,5,9,13,25,26)}$.

Serra-Doria et al. ${ }^{(30,31)}$ had the idea for the Serra-Doria surgery based on their experience. The great merit of the present study was the selection of patients with the same disease grade, since the 19 patients of the series had advanced megaesophagus and no clinical conditions to undergo esophagectomy, which would be the procedure of choice for advanced megaesophagus, as it has been recommended by many authors ${ }^{(3,9,20,21,22,24)}$.

Patients who are not surgery naïve have many adhesions between the esophagogastric transition and the neighboring structures, making the esophageal dissection more vulnerable to complications, such as perforation, pleural lesion, and consequently, pneumothorax. Additionally, 
since the esophagogastric transition requires greater dissection, vascularization may be further impaired, possibly resulting in a leakage of the esophagogastric suture and consequently, a fistula, as some series have reported ${ }^{(4,9,13,25)}$. This was well described by Ponciano et. al. ${ }^{(25)}$, who analyzed 20 patients with initial and advanced megaesophagus submitted to the Serra-Doria surgery because of symptom recurrence after cardiomyotomy; $10 \%$ of their sample had an esophagogastric anastomotic fistula. The patients recovered well with parenteral nutrition and did not require another surgery, despite the long hospital stay ${ }^{(25)}$. One (5\%) patient presented pneumothorax, which required thoracic catheter, but the patient also recovered well. Silva Dória ${ }^{(32)}$ demonstrated his extensive experience with the Serra-Doria technique in 410 patients who had all grades of megaesophagus. Of the four $(1 \%)$ deaths, one was caused by esophagogastric anastomotic fistula ${ }^{(32)}$. The esophagus of this specific patient had a very large diameter, which hindered dissection and probably predisposed him to an anastomotic fistula.

This occurrence was also observed in the present sample, since one patient presented a fistula stemming from esophagogastric anastomotic leakage, but he recovered well with conservative treatment despite the long hospital stay. The esophagus of one patient was perforated during surgery, which have resulted from the difficulty of dissecting the structure because of postoperative adhesions and large esophageal diameter. Despite this complication, the patient recovered well and did not have any systemic repercussions, as the perforation was fixed during surgery.

Pulmonary infection, experienced by four patients, possibly stemmed from malnutrition, which manifests in patients with megaesophagus, predisposing them to infections. Some patients also have greater lung vulnerability because of smoking, and these four patients were smokers. This type of complication has also been reported by other authors ${ }^{(4,5,9,25)}$. The same occurred regarding arrhythmia in one of these patients, which may be explained by his advanced age and associated chagasic heart disease.

Although early assessment revealed few complications for the Serra-Doria procedure, some studies with long-term follow-ups have had difficulties assessing the real benefit of this procedure, which is to correct swallowing. This occurs because some patients are lost to follow-up and some have different megaesophagus grades, which hinders the comparison of outcomes. Ponciano et al. ${ }^{(25)}$ made this very evident: they studies 20 patients with recurrent megaesophagus of different grades and found that $42.2 \%$ of the patients presented mild to moderate dysphagia in a mean follow-up time of 22.3 months, and only $29.4 \%$ of the patients gained weight. Nevertheless, patients with advanced megaesophagus had greater incidence of symptom recurrence, especially dysphagia. One may infer that these authors could have indicated the SerraDoria procedure for patients with the same disease grade or with less advanced disease to obtain better outcomes. Alves et. al. ${ }^{(1)}$ also observed good outcomes in $92.5 \%$ of 50 patients with advanced megaesophagus, recurrent or not. Yet these same authors mention the importance of long-term follow- up to confirm the validity of the Serra-Doria procedure for advanced megaesophagus, since the follow-up time was only 30 days after surgery.

As these authors have emphasized, it is important to follow esophagocardioplasty patients for many years to better assess the real incidence of symptom recurrence. Still, this is often hard to accomplish due to losses to follow-up, which also occurred in the present sample: six of the 19 patients did not attend the five-year follow-up.

This long-term symptom recurrence was well demonstrated in the present sample, since $94.7 \%$ of the patients had normal swallowing in the one-year follow-up. In the threeyear and five-year follow-ups, only $62.5 \%$ and $38.4 \%$ of the patients had normal swallowing, and two (15.3\%) patients complained of severe dysphagia and weight loss. Vomiting presented a very similar pattern: no patient complained of vomiting in the one-year follow-up, but more than $50 \%$ of the patients complained of vomiting in the five-year followup, similar to the preoperative percentage.

Treatment deterioration probably stems from lower esophageal motility in patients with advanced disease and chagasic megaesophagus, as confirmed by many manometric studies $^{(4,5,9)}$. Treatment deterioration was also well evidenced by the present study, as nine patients submitted to esophageal manometry before surgery had mean esophageal contraction amplitude below $15 \mathrm{mmHg}$.

\section{CONCLUSION}

Serra-Doria esophagocardioplasty for the treatment of advanced recurrent megaesophagus had mild postoperative complications and good success rate in the short-term follow-up. In the long-term follow-up, it proved to be a poor surgery choice because of the high incidence of symptom recurrence, compromising quality of life. This procedure should be indicated only for patients with advanced recurrent megaesophagus without clinical conditions to undergo esophageal resection.

\section{Study limitations}

The main limitations of this study were the exclusive inclusion of patients with advanced recurrent chagasic megaesophagus and patients who had undergone the same surgery: cardiomyotomy. These selection criteria aimed to homogenize the sample. Another study limitation was the long-term assessment, which allowed assessing all patients 1 year after surgery. Only thirteen of the nineteen patients attended the five-year follow-up, as six were lost to follow-up. For all these reasons this study included only 19 patients.

\section{Authors' contributions}

All authors helped to collect data and write the manuscript and the authors read and approved the final manuscript.

\section{ACKNOWLEDGMENTS}

Pontifical Catholic University of Campinas-SP-Brazil. 
Aquino JLB, Said MM, Pereira DAR, Leandro-Merhi VA, Nascimento PC, Reis VV. Avaliação precoce e tardia da esofagocardioplastia no tratamento cirúrgico do megaesôfago avançado e recidivado. Arq Gastroenterol. 2016,53(4):235-9.

RESUMO - Contexto - A doença de Chagas, por apresentar manifestações esofágicas com diferentes graus de acometimento, faz com que haja controvérsias quanto a melhor opção cirúrgica; principalmente para pacientes com megaesôfago chagásico avançado e com recidiva de sintomas após tratamento prévio. Objetivo - Avaliar o resultado precoce e tardio da esofagocardioplastia em uma série de pacientes com megaesôfago chagásico avançado e recidivado. Métodos - Estudo descritivo, com 19 pacientes idosos com megaesôfago Grau III/IV recidivado e com imunoflorescência positiva para doença de Chagas. A cirurgia prévia foi a cardiomiotomia com fundoplicatura anterior, com tempo médio de realização de 16,5 anos. A cirurgia de eleição para o tratamento da recidiva foi a esofagocardioplastia de Serra-Dória. Realizou-se avaliação precoce para estudar as complicações pós-operatórias e tardias, para avaliar a incidência de recidiva de sintomas. Resultados - Na avaliação precoce, $5(26,3 \%)$ pacientes apresentaram complicações clínicas. Um $(5,2 \%)$ paciente apresentou fístula digestiva consequente a deiscência da anastomose esofagogástrica, mas com boa evolução com o tratamento conservador. Na avaliação de 1 ano de pós-operatório, $18(94,7 \%)$ pacientes apresentavam deglutição normal e sem regurgitação. Com 3 anos de pós-operatório, de 16 pacientes analisados; 10 (62,5\%) pacientes apresentavam deglutição normal e 3 (19,3\%) se queixavam de regurgitação. Com 5 anos de pós-operatório, de 13 pacientes analisados; somente 5 $(38,4 \%)$ apresentavam deglutição normal e $7(53.8 \%)$ com regurgitação. Conclusão - A esofagocardioplastia de Serra-Dória, no tratamento cirúrgico do megaesôfago avançado recidivado, apresentou complicações pósoperatórias de baixa morbidade e com boa resolutividade, na avaliação precoce. Na avaliação de longo prazo, demonstrou não ser um procedimento cirúrgico adequado, pela alta incidência de recidiva de sintomas, com comprometimento da qualidade de vida. Deve ser indicada somente em pacientes com doença avançada recidivada, sem condições clínicas de serem submetidas à ressecção esofágica.

DESCRITORES - Acalásia esofágica, cirurgia. Esofagoplastia. Recidiva. Doença de Chagas, cirurgia. Idoso.

\section{REFERENCES}

1. Alves L, Zilberstein B, Trevenzol HP, Penhavel FAZ, Neder J. Operação de Serra-Dória no tratamento do megaesôfago chagásico avançado: resultados imediatos. Arq. Bras Cir Dig. 2003;16:120-23.

2. Aquino JLB. Terapêutica do Megaesôfago Avançado pela Mucosectomia com conservação da túnica muscular. Tese de Doutorado, Campinas. Faculdade de Ciências Médicas da UNICAMP, 1996.

3. Aquino JLB, Reis Neto JÁ, Muraro COM, Camargo JGT. Mucosectomia esofágica no tratamento do megaesôfago avançado: análise de 60 casos. Rev Col Bras Cir. 2000;27:109-16.

4. Aquino JLB, Said MM, Pereira Eva, Vernachi B, Oliveira MB. Terapêutica cirúrgica do Megaesôfago Recidivado. Revista do Colégio Brasileiro de Cirurgiões. 2007;34:310-3.

5. Aquino JLB, Said MM, Leandro-Merhi VA, Ramos JP, Ichinohe LH, Machado DGG. Avaliação da esofagocardioplastia no tratamento cirúrgico do megaesôfago não avançado recidivado. ABCD Arq Bras Cir Dig. 2012;25:20-4.

6. Barbosa H, Barichello AW, Mendelssonh P, Viana AL, Watanabe LM. Tratamento cirúrgico do megaesôfago chagásico: duas décadas de experiência numa região endêmica. Rev. Goiana Med. 1989;35:1-23.

7. Bonatti H, Hinder RA, Klocker J, Neuhauser B, Klaus A, Achem SR. Long-term results of laparoscopic Heller myotomy with partial fundoplication for treatment of achalasia. Am J Surg. 2005;190:874-8.

8. Carrilho RP. Estudo longitudinal de 25 anos da Doença de Chagas em Mambaí/ Buritinopolis(GO)- Brasil. Tese de Doutorado, Universidade de Brasilia (UnB), Brasilia, DF, 2001.

9. Chuah SK, Chiu CH, Tai WC, Lee JH, Lu HI, Chang CS. Current status in the treatment: options for esophageal achalasia. World J Gastroenterol. 2014;19:5421-9.

10. Csendes A. Results of surgical treatment of achalasia of the esophagus. Hepatogastroenterology. 1991:38:474 -80.

11. Del Grande JC, Herbella FAM. Megaêsofago: Perpectivas futuras. In: Nakano SMS, Faintuch J, Ceconello I. Megaesôfago Chagásico: Avaliação e tratamento clínico e cirúrgico. $1^{\text {a }}$ Ed. Goiânia Editora da Universidade de Goiás, 2006. 375-80.

12. Dias JC, Silveira AC, Schfield CJ. The impact of Chagas disease control in Latin America: a review. Mem. Instituto Oswaldo Cruz. 2002;97:603-12

13. Goldenberg S. Cirurgia do megaesôfago - operação de Grondhal Doria modificada. Rev. Goiania Med. 1973;19:195-201.

14. Gröndahl NB. Cardiaplastik Ved Cardiospasmus. Nord Kirurgisk Forenings. 1916;11:236-40.

15. Grotenhius BA, Wijnhoven BPL, Myers JC, Jamieson GG, Devitt PG, Watson DI. Reoperation for dysphagia after cardiomyotomy for achalasia. The American Journal of Surgery. 2007;194:678-82.

16. Herbella Fam, Del Grande JC, Lourenço LG, Mansur NS, Haddad CM Resultados tardios da operação de Heller associada a fundoplicatura no tratamento do megaesôfago: análise de 83 casos. Rev Associação Médica Brasileira. 1999;45:17-22.
17. Holt CJ, Large AM. Surgical management of reflux esophagitis. Ann Surg. 1961;153:555-63.

18. Lopes, LR. Resultados imediatos e tardios do tratamento cirúrgico do megaesôfago não avançado pela técnica de Heller-Pinotti: Laparotomia versus Laparosocópia. Tese de Livre Docência, Campinas: Faculdade de Ciências Medicas da UNICAMP, 2008.

19. Martins P, Morais BB, Cunha Mello JR. Postoperative Complications in the treatment of Chagasic Megaesophagus. Int. Surg. 1993;78:99-102.

20. Miller DL, Allen MS, Trastek VF . Esophageal resection for recurrent Achalasia. Ann Thorac Surg. 1995;60:992-6.

21. Muraro CPM, Camargo JGT, Aquino JLB. Megasôfago. In: Muraro CPM. Cirurgia do Aparelho Digestório. $1^{\text {a }}$ ed. Rio de Janeiro, Editora Rubio, 2009,19-27.

22. Orringer MB, Marshall B, Chang AC, Lee J, Pickens A, Lau CL. Two Thousand Transhiatal Esophagectomies. Changing Trends, Lessons learned. Ann Surg. 2007;246:363-74.

23. Pearson FG. Achalasia - Long Term Follow -up and late complications. Brasilia Med. 1995;32(3/4):34:6.

24. Pinotti HW, Felix VN. Reoperação no megaesofago recidivado por transecção mediana do diafragma. In: Pinotti HW. Acesso ao esôfago toracico por transecção mediana do diafragma. São Paulo, Atheneu, $1^{\text {a }}$ ed., 1999, p.121-8.

25. Ponciano H, Ceconello I, Alves L, Ferreira BD, Gama-Rodrigues JJ. Cardioplasty and Roux in Y parcial gastrectomy (Serra-Doria procedure) for reoperation of achalasia. Arq. Gastroenterol. 2004;41:155-61.

26. Ramos DM, Sos JE, Yepes VA, Sanchis JLS. Tecnica de Serra-Doria: Um buen recurso para el tratamiento de la acalasia esofágica recidivada. Cir. Esp. 2006;80;340-4.

27. Rezende JM, Lauar KM, Oliveira AR. Aspectos clínicos e radiológicos da aperistalse do esôfago. Rev Bras.Gastroenter. 1960;12:247-51.

28. Richards WO, Torquati A, Holzman M. Heller myotomy versus Heller myotomy with Dor fundoplication for Achalasia: a prospective randomized double- blind clinical trial. Ann Surg. 2004:240:412-5.

29. Serra HO, Felix VN, Ceconello I, Pinotti, HW. Reaplication of Myotomy and fundoplication in the surgical treatment of recurrent dysphagia after incomplete myotomy. Rev Hosp Clin Fac Med São Paulo. 1998;53:129-33.

30. Serra-Doria OB, Silva-Doria OM, Silva- Doria OR. Nova conduta cirúrgica para o tratamento do megaesôfago. An Paul Med Cir. 1970;97:115 -21.

31. Serra-Dória OB, Silva Dória OM, Silva Dória OR. Operação de Serra-Dória para tratamento do megaesôfago. Considerações quanto a originalidade do método. An Paul Med Cir. 1972; 99:113-20.

32. Silva Doria O. Operação de Serra-Dória. In: Nakano SMS, Faintuch J, Ceconello I. Megaesôfago chagásico. Avaliação e tratamento clinico e cirúrgico. $1^{\mathrm{a}}$ ed. Goiana. Editora da Universidade de Goias, 2006. p.221-40. 